\title{
Legal mechanism of protection from social risks: a value-based approach
}

\author{
Marina Yur'evna Fedorova', Yelena Alexandrovna Istomina, ${ }^{2, *}$ \\ ${ }^{1}$ Constitutional Court of Russian Federation, Saint-Petersburg, 190000, Russia \\ ${ }^{2}$ Department of Labour Law, Ural State Law University, Yekaterinburg, 620137, Russia
}

\begin{abstract}
Protecting people from social risks is an important task for any state and society. Such protection is complex; it combines organizational measures, financial resources, and law. They form a united system, which we call the social risk management system. This system is based on a legal mechanism. Its social value consists in the fact that different branches of law make it possible to guarantee protection at different stages of the risk dynamics. The right also allows an individual to apply for protection, including to the Constitutional Court of the Russian Federation. Using the example of protection from social risks associated with family responsibilities, the authors show the functioning of the legal mechanism for managing social risks and its importance.
\end{abstract}

\section{Introduction}

Individuals and humanity development is largely connected, on the one hand, with the need to work - to carry out appropriate activities that bring the desired result (livelihood), on the other - the need for protection by family, to take care of loved ones. This allowed people to survive and develop. At a certain point, they formed a society.

The results of the work, family support allow us to meet the most important needs - this is their meaning and social value. This value does not depend on the socio-economic and political circumstances. As before, in order to live, you need both work and interact with people. However, this may be difficult or even not possible due to different circumstances emergence. They can differ by their nature, but are united in their consequences - they are negative, make it difficult for a person to live, work and develop.

Such circumstances - various dangers of natural, industrial, economic and even social nature. Science calls them risks. Recently, risk is rarely understood as an action in the hope of good luck, to get a positive and partly unexpected result [1]. Risk is now considered as an alarming uncertainty, as a danger. The most significant risks that make people's lives difficult are called social risks $[2,3]$. The state - the result of the development of society, its superstructure - declares the highest value of life and human rights, and therefore assumes the obligation to protect people, especially vulnerable ones, from these risks. These obligations form part of the social policy, which, in accordance with Art.7 of the Constitution of the Russian Federation, is aimed at creating conditions that ensure a decent life and development of a person. However, not only welfare states, but also other actors influence on social risks. These are employers, charities, families, etc.

Therefore, we believe that social risk, caused by the biosocial nature of a person and the laws of the development of society, can be considered as the probability of situations that make it difficult to independently meet vital needs. This probability, its negative effects are fixed in social security law. Prevention, overcoming and compensation of social risks are carried out by the society, the state, and other social institutions.

\section{Results and Discussion}

\subsection{The social value of the legal mechanism of protection from social risks}

The term "protection", as a rule, means "to take under protection, to defend". However, it also has another connotation - "to protect from external influences", "to prevent changes that are undesirable". Therefore, protection from social risks is an activity that is aimed at restoring or maintaining a person's health and life. This activity has a complex character, and is built in a certain sequence.

First, social risk is not only a circumstance that leads to negative effects, and not only the probability of such effects. Any social risk emerges consistently - the risk event first, then - its negative effects. In some cases, the external conditions that lead to risk also matter.

Second, the dynamics of risk determines the protection from it. The protection should be directly addressed to the person who has faced the risk. It may be social benefits as the negative effects compensation, by 
social security law, or finding a suitable work, sick for work-life balance, by labour law, etc. Even ecological risks prevention is involved is this. This may also be an activity that is not directly aimed at a person, but is related to risk compensation and prevention - risk assessment, forecasting, and protection financing.

Third, protection from social risk is carried out on the basis of a complex mechanism, which we propose to call the social risk management system. As a rule, management is considered as a constant action, a purposeful influence of manager on an object or on a system, which result is the accomplishment of desired manager's goals - some new state by the object or by the system, corresponding to the needs of the manager. The social risk management system includes economic means (financial resources), organizational means (the institution that makes both general and individual decisions to protect from risks), and, of course, legal means.

Thus, protection from social risk can be defined as a complex activity aimed at preventing, overcoming or compensating for negative effects of social risks, in order to restore human life. Such protection is impossible without fixing rules for its implementation in the law, due to its importance for all the society. It cannot exist without legal regulation. The law gives stability to this sphere, allows individuals and states to exercise their rights and obligations, to ensure the achievement of their interests on the basis of the law. The law "connects" to protection form social risks when it becomes guaranteed, and the state becomes its main participant, setting the necessary rules, imposing obligations on other actors (for example, employers must pay social security contributions, the Pension Fund of the Russian Federation - pays compulsory pensions, etc.).

Therefore, we believe that an important element of the social risk management system is the legal mechanism. That is, a complex multi-level set of legal rules that are linked to each other guarantees the preparation, adoption, implementation and evaluation of the effectiveness of management decisions with the aim of protecting from social risks by preventing, overcoming them, or compensating for their negative effects. The law does not just fix some events and actions, it should actively promote the emergence of new participants, new economic and legal states, and promote economic development [5].

The formation of a legal mechanism of social risks managing and its acting is based on certain values. The general value of law in this area is, first of all, that it gives this activity, based on social solidarity, stability, taking into account other social rules (moral, religious, etc.). However, it is not limited to this.

The value of the law also involves the fact that it must fix the circumstances giving right to protection, as well as the ways provided for in each case. Currently, society's ideas about when the state should protect a person from social risks are concentrated in international human rights instruments. Social protection international standards combine the best achievements of humanitarian science and legislation of different states.
For example, the right to social security, including social insurance is proclaimed by art. 9 of the International Covenant on Economic, Social and Cultural Rights (adopted by General Assembly resolution 2200A (XXI), New York, December 16th, 1966). Developing this right, the Covenant fixes the widest possible family protection and assistance, a special protection to mothers before and after childbirth, to all children. The States Parties to the Covenant must recognize the right of everyone to an adequate standard of living for himself and his family, including adequate food (to be free from hunger), clothing and housing, to the continuous improvement of living conditions, and also to the highest attainable standard of physical and mental health. The Social Security Convention No.102 by International Labour Organization (June 28th, 1952) proclaims minimum standards of social security as for medical care; sickness benefit; unemployment benefit; old-age benefit; employment injury benefit; maternity and family benefit; etc. These standards have been developed in in constitutions of most states, including the Constitution of the Russian Federation.

Therefore, we can say that by now all the main social risks and the right to protection from them, including social security, have been enshrined in the law. The risks can be united into four groups - the risks of disability, the risks of unemployment, the risks associated with family responsibilities, and the risk of poverty. Depending on the risk, the legal regulation of protection is organized. The Russian laws are structured in the necessary way (mandatory or additional social insurance, social assistance), due to the absence of the Social Security Code.

The complexity of the system of protection from social risks involves the use of various branches of law. We can note constitutional, administrative, financial, civil, criminal, family, labour law, social security law and other branches of Russian law in this sphere. And, although the right to social security is most often involved (the right to social security; cases and conditions of social security, types, size of social benefits; applying for social benefits, etc.), the importance of other branches of law cannot be reduced. The synchronization of social security policy with employment and labour market policies is important to ensure positive synergies and joint effectiveness in providing access to work opportunities in the formal sectors of the economy, which is key to tackling poverty and social exclusion and to enabling the poor greater access to more comprehensive forms of social security protection. Good governance will better ensure the sustained and lasting contribution of social security to national economic growth and development [6].

\subsection{Social risks associated with family responsibilities: protection features and its social value}

The family is the primary group of society, it unites working-age persons, their disabled (due to age, disability) relatives, children. Maintaining today's 
families via the kin-keeping role may be increasingly difficult. So, people face to different social risks associated with family responsibilities. The need to care for elderly and dependent relatives generates negative effects for employment, for income level. Today caring for a dependent elderly family member and employment are competing demands both for men and women [7].

First of all, social risks are associated with birth and childcare. The rights of the child are a priority of the policy of any state, of the entire world community. It is underlined in the Convention on the Rights of the Child (adopted by UN General Assembly resolution 44/25 of November 20th, 1989), that the child, by reason of his physical and mental immaturity, needs special safeguards and care, including appropriate legal protection, before as well as after birth. Therefore, protection from social risks associated with family responsibilities (first of all - with child's care) is based on family legislation (the Family Code of the Russian Federation adopted on December 29th, 1995, N 223-FL). It enshrines the right of every child to live and be brought up in a family, the right to know their parents, to their care, the responsibility of parents for the upbringing and development of their children, for their health and development. This goal is also reflected in the social security legislation, where some benefits are restricted to persons committing violations against children. For example, in accordance with the Federal Law "On additional measures of State support for families with children" (adopted on December, 29th, 2006), a woman who has been deprived of parental rights due to failure to fulfil the duties of a parent, abuse of parental rights, abuse of a child, is deprived of the right to maternity capital. Thus, the norms of family law and social security law act together in aiming to prevent the orphanhood social risk.

The social risks associated with family responsibilities are special, as they require prevention not of their external causes, not of risk events, but of negative effects. These social risks are an example of a state priority in protection. In Russia there are additional benefits that are aimed at achieving the goals of a state demographic policy.

The problem of depopulation of Russia is becoming more and more serious. According to the Forecast of socio-economic development of Russia until 2030, the country will not be able to avoid an increase in the demographic burden in any case. Despite the decline in the working-age population (to 81.3 million people by 2030 ), the demographic burden will increase to 878 disabled people per 1,000 people of working age by 2030 (the population over the working age will increase to 43.5 million people).

In addition, the decline in the population in Russia over the past decades has been facilitated not only by a decrease in the birth rate, but also by a decrease in the number of marriages and an increase in the number of divorces, an increase in the number of childless couples, as well as individualization, the desire for personal freedom. The main goal declared by the Russian government - the satisfaction of individual needs, as opposed to the primary interests of society, contributed to the establishment of this principle in the mass consciousness of people. Globalization has also had an impact [8].

Therefore, the state strives to promote family values, and also supports the birth of children. Protection of the family, motherhood, fatherhood and childhood; of the institution of marriage as a union of men and women; creation of conditions for the decent upbringing of children, as well as for the implementation of adult children's duty to take care of their parents - the principles that have been included in the Constitution of the Russian Federation. They have a direct effect and are developed in national legislation. Children are the main priority of Russian social policy. The state creates conditions that should help the moral, intellectual and physical development of children, education in them of patriotism and respect for their elders.

The appearance of a child in the family is a social risk, when a good event (in terms of its meaning) causes negative effects - a decrease in the family income, since the mother or father must leave work and take care of the child. In addition, the family has additional expenses. Therefore, persons with family responsibilities in labour law and in social security law are called vulnerable, in need of increased protection.

It should also be noted that other risks may emerge. An employee with a child is more vulnerable in the labour market; it is more difficult for him to find a job, if only because of the lack of time to search for it. In addition, such an employee does not always seem reliable to the employer. The active influx of women into the labour market, the decline of the male breadwinner family and changing gender norms create new social risks for both men and women. Women and men with inadequate access to adequately paid leave or care facilities are facing a risk of being forced to either exiting the labour market or reducing their time in paid work because of care responsibilities [9].

International human rights instruments set out the protection from the social risks associated with family responsibilities as general principles. Previously, this was associated with problems that only occurred in women caring for children, but later this standard was extended to working men. The Workers with Family Responsibilities Convention C156 (adopted by ILO on June 23th, 1981) insists that all persons with family responsibilities who are engaged or wish to engage in employment could exercise their right without being subject to discrimination and, to the extent possible, without conflict between their employment and family responsibilities. It also points out the necessity of creating effective equality of opportunity and treatment as between men and women workers with family responsibilities and between such workers and other workers.

The family social value understanding, the principle of protection of motherhood and childhood in the Constitution of the Russian Federation contributed to the fact that these rules were developed in the Russian legislation. This is not only a statement of social risk, but also the features of its manifestations. For persons with family responsibilities, the labour legislation establishes 
additional guarantees. For example, in Russia there is the restriction of fixed-term employment contracts, the restriction of dismissals at the employer initiative, special guarantees related to working at night, with business trips, etc.

In addition, the inability to meet vital needs, caused by the loss of earnings or increased family expenses, led to the establishment of various benefits in the legislation, which differ in the type, size, and duration of payment. It is also emphasized by the main policy documents adopted in our country. Thus, one of the five Federal projects of the National Project "Demography" is the project "Financial support at the birth of children", which aims to significantly increase by 2024 the number of families receiving benefits in connection with the birth or adoption of children who have received a certificate for maternity capital and have disposed of funds. This Project also involves measures aimed at maintaining the birth rate in certain regions of the Russian Federation, and at preserving and popularizing family values.

Therefore, the provision of social benefits, services, and benefits to families with children is logically considered as one of the main measures of protection from the negative effects of social risk. It should be noted that since the $90 \mathrm{~s}$ of the twentieth century, legislation in this area has been dynamically developing. To date, the Russian social benefits system for families with children is quite extensive and allows you to receive benefits and services, depending on the presence of one or more children in the family, the family's income level, place of residence, and other circumstances.

Social benefits are also evolving. For example, in recent years, the rules for providing maternity capital have been significantly changed. In 2015 , a new way of its use appeared - the purchase of goods and services for the social adaptation and integration of disabled children into society. Since January 1th, 2018, a monthly benefit in connection with the birth or adoption of a child has been introduced (at first, this rule applied only to benefits in connection with the birth of a second child, now - also of the first one) as an aid with the family increased expenses. This happens when the level of the average per capita income does not exceed twice the living wage. The amount of the payment is the living wage for children.

In 2020, due to the pandemic of a new coronavirus infection, new benefits to all families with children were fixed in the legislation. They were essentially universal and extraordinary. In accordance with the Decree of the President of the Russian Federation No. 249 "On additional measures of social support for families with children" (signed on April 7th, 2020), a parent entitled to maternal (family) capital could receive five thousand roubles during three months. The unusual feature of such payments was that they were not included in the family income, so they were not taken into account when determining the right to social assistance for the poor.

Moreover, since last year, various monthly benefits have been introduced to families with children, if the average per capita income of the family does not exceed the living wage per capita established in the subject of the Russian Federation. The amount of these payments is differentiated depending on the income, taking it into account - from $50 \%$ to $100 \%$ of the living wage for children.

The value of the legal mechanism of protection from social risks is also confirmed by the fact that its functioning is guaranteed by the Constitutional Court of the Russian Federation in such a way that it complies with the Basic Law of our country. Politicians and academics have emphasized the role of social rights for providing social and economic development. The main argument for a rights-based approach to development is that it gives an entitlement that can be enforced in court. Without such a right, people are fully dependent on the 'good-will' of the government of that time for proper education, health care and social security. The constitution can play an important role for social rights, as constitutions provide universal rights for everyone [10].

Thus, with regard to protection from negative effects of the social risks associated with family responsibilities, the Constitutional Court of the Russian Federation has pronounced a number of judgements in cases regarding the guarantees to workers with families. For example, it can be ensured by creating better conditions for combining work and family responsibilities. At the same time, it is necessary to observe the constitutional principles of justice, equality and the social state. For example, the Judgement No. 28 (December 15th, 2011) has recognized Art. 261 p. 4 of the Labor Code of the Russian Federation as not conforming to the Constitution of the Russian Federation. It allowed the dismissal of the father - the only breadwinner in a large family with young children (including a child under three years old), where the mother does not work and is engaged in child care.

According to the mentioned judgement state support for the family, motherhood, fatherhood and childhood is aimed at increasing the birth rate as an important condition for the development of the multinational people of Russia. At present, this support is of particular social importance, is a priority task of the Russian demographic policy and assumes the existence of legal rules, the purpose of which is to guarantee the family effective protection. Such protection should be adequate to the socio-economic policy of the country at the moment, as well as to the level of economic development and financial resources. The Constitutional Court of the Russian Federation stressed that the guarantees are necessary not only to achieve de facto equality of opportunities in the field of work, but are explained by the economic and social vulnerability of a family with minor children. In other words, they are aimed at preventing family poverty and should allow protecting the rights and interests of the child, providing him with conditions for decent development. A similar goal was noted by the Constitutional Court of the Russian Federation regarding the termination of contracts with military, police and penal institutions personnel - single mothers with children under the age of 14 (Judgements No. 21 (October 15th, 2013), No. 2 (January 12th, 2018), No. 26 (May 27th, 2020)). 
The Constitutional Court of the Russian Federation spoke about the need for decent benefits aimed at the social risks compensation associated with the birth of children and providing them with proper care in its Judgement No. 4 (March 22th, 2007) when examining the issue of determining the maximum amount of maternity benefits for women - subject to mandatory social insurance, as well as in its Judgement No. 13 (March 27th, 2018), assessing the Stavropol region legislation on additional social support for large families.

Along with improving protection from social risks associated with family responsibilities, the judgements and decisions by the Constitutional Court of the Russian Federation considered the implementation of the constitutional right to social security in the case of social risks of old age, disability, unemployment, etc. Thus, the legal positions formulated by the Court concern a wide variety of issues of protection from social risks, which should be based on constitutional principles and regulations.

\section{Conclusions}

The legal mechanism of protection from social risks involves the risk management on the basis of law. The rules in the legislation affect social risks at different stages of their emergence. Along with compensating for their negative effects, it is important to prevent risk events and minimize risks. Protection from social risks is carried out with the help of various branches of law constitutional, administrative, financial, civil, labour, environmental, etc.

Social risks threaten what is of particular importance for a person and for society - life and health, human dignity, work, family, motherhood and childhood, environmental safety, etc. Protection from these risks is a social and legal value, as it is based on international and constitutional principles, on human rights, provided with legal guarantees, including judicial protection, including by the Constitutional Court of the Russian Federation.

\section{References}

1. J. Navarro, Epistemic Luck and Epistemic Risk (Erkenn, 2021). DOI: https://doi.org/10.1007/s10670-021-00387-9

2. R. Holzmann, V. Kozel, IDS Bulletin, 38 (2007). DOI: https://doi.org/10.1111/j.17595436.2007.tb00364.x

3. G. Bonoli, Policy \& Politics, 33(3) (2005). DOI: https://doi.org/10.1332/0305573054325765

4. R. Lidskog, G. Sundqvist, Essentials of Risk Theory (Springer, 2013)

5. Yu. A. Tihomirov, E.V. Talapina, Law. Journal of Higher School of Economics, 1 (2020). DOI: 10.17323/2072-8166.2020.1.4.26

6. A. R. Musalem, M. D. Ortiz, International Social Security Review, 64 (2011). DOI: https://doi.org/10.1111/j.1468-246X.2011.01409.x

7. J. Singleton, Journal of Comparative Family Studies 31(3) (2000). DOI: https://doi.org/10.3138/jcfs.31.3.367

8. I. F. Dementyeva, Theory and practice of social development, 2 (2014)

9. A. Ejrnæs, T.P. Boje, New Social Risks and WorkFamily Balance, in: Family Well-Being, vol. 49, pp. 131-149 (Springer, 2013). DOI: https://doi.org/10.1007/978-94-007-4354-0_7

10. E. Cammeraat, Review of Law \& Economics, 17(1) (2021). DOI: https://doi.org/10.1515/rle-2019-0051 